\title{
IMPLEMENTATION OF AUTOMATIC SAMPLE AND COMPOSITE ELEMENT CUTTING TECHNOLOGIES
}

\author{
Robert Jaśkiewicz \\ Institute of Aviation, Center for Composite Technologies \\ al. Krakowska 110/114, 02-256 Warsaw, Poland \\ robert.jaskiewicz@ilot.edu.pl
}

\begin{abstract}
The article presents the methodology of introducing automatic carbon fiber panel cutting technologies at the Composite Testing Laboratory of the Institute of Aviation. It describes the process of implementing the new cutting technology which boosts the efficiency of preparing composite samples for strength testing, with the requirements applicable to edge smoothness and dimension tolerances taken into consideration. It also reviews the literature concerned with three most popular composite material cutting methods: laser cutting, abrasive water jet cutting and machining, presenting the strong and the weak points of each one of them. After selecting the machining technology relying on a disc, cutting tests have been performed. Cutting discs coated with diamond particles, and carbon fiber panels were used during the tests. The tests were performed with the use of the INFOTEC CNC machine, with an adapter enabling the installation of cutting discs with the maximum diameter of $150 \mathrm{~mm}$.
\end{abstract}

Keywords: composite cutting, automatic cutting, CNC cutting, carbon fiber machining.

\section{INTRODUCTION}

The growing number of CFRP applications results in the need to use ever quicker and more precise methods of machining such materials. Carbon fiber composites are difficult to machine, as the process is likely to cause defects (Fig. 1) [1,19]. The defects are often unacceptable due to the changes in the mechanical properties they induce. Samples machined in preparation for strength testing must conform to the most stringent quality standards, as their precision directly impact the results of the tests performed. This means that machining has to be highly precise, with small shape and dimension tolerances. Defects that affect mechanical properties of the materials tested are unacceptable as well. 


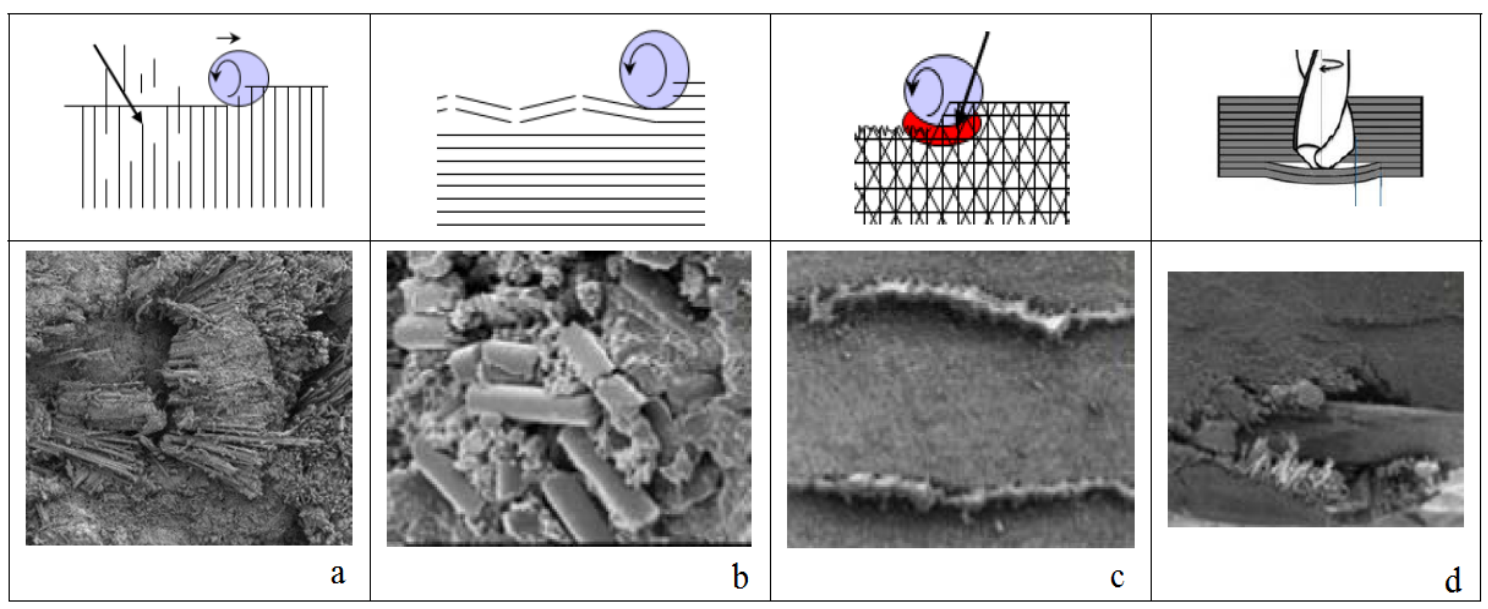

Fig. 1. Defects caused while machining carbon fiber materials: a - torn fibers, b - broken fibers, c - fiber mesh distortions, $\mathrm{d}$ - delamination [1]

Ultimate strength tests of composite materials are not time-intensive. It usually takes not more than thirty minutes to test a typical sample. Preparation of the sample for the test, however, is much more time consuming. It requires that a carbon fiber panel be manufactured and cut into samples, with their edges often in need of grinding as well. Depending on the type of the test performed, some samples need to undergo additional processes, e.g. tabs bonding suitable for the clamps of the testing device, drilling holes or undergoing an additional thermal cycle. All such operations are performed with due care and take much more time than the strength test itself. Therefore, the Composite Testing Laboratory relies on an automated cutting process performed at its new sample preparation facility. The workshop has been equipped with new tools selected based on an analysis of the CFRP cutting methods and solutions currently available on the market.

\section{REVIEW OF CFRP MACHINING METHODS}

Three most popular industrial technologies used for cutting carbon fiber composites have been selected for the analysis: laser cutting, abrasive water jet cutting and machining. Each of those methods offers its own advantages and disadvantages. Each requires also specific capital expenditure that needs to be considered in the context of the quantities of materials processed and quality levels expected.

\subsection{Cutting composite materials with laser}

The laser cutting technology offers a good chance of CFRP being machined in mass production settings. Implementation of the laser cutting technology requires considerable investment, but the solution may be easily automated and is very efficient as well. The cutting speed depends on the power of the laser used. The power of the laser determines also the size of the Heat Affected Zone (HAZ), which should be reduced to the minimum. It is of utmost importance to properly control the zone impacted by the cutting process, as once the glass transition temperature is reached, the properties of the material will be affected irreversibly. 
Laser cutting of carbon fiber materials enables to obtain a very good quality of the cutting edges. If the parameters of the process are selected correctly, the technology minimizes or even eliminates the problem of edge fraying and delamination. Selection of the proper type of the laser, its power output and the speed of cutting are among the most crucial parameters that need to be taken into consideration.

In article [2], its authors note that infrared lasers with the power output of several $\mathrm{kW}$ are capable of cutting carbon fiber very quickly (several hundred $\mathrm{mm} / \mathrm{s}$ ), but their heat affected zone is unacceptably large. They also note that a pulse-controlled UV laser is capable of minimizing the amount of trimmed edge defects, and of reducing the heat affected zone to as little as $15 \mu \mathrm{m}$ (Fig. 2) [2,11,12].

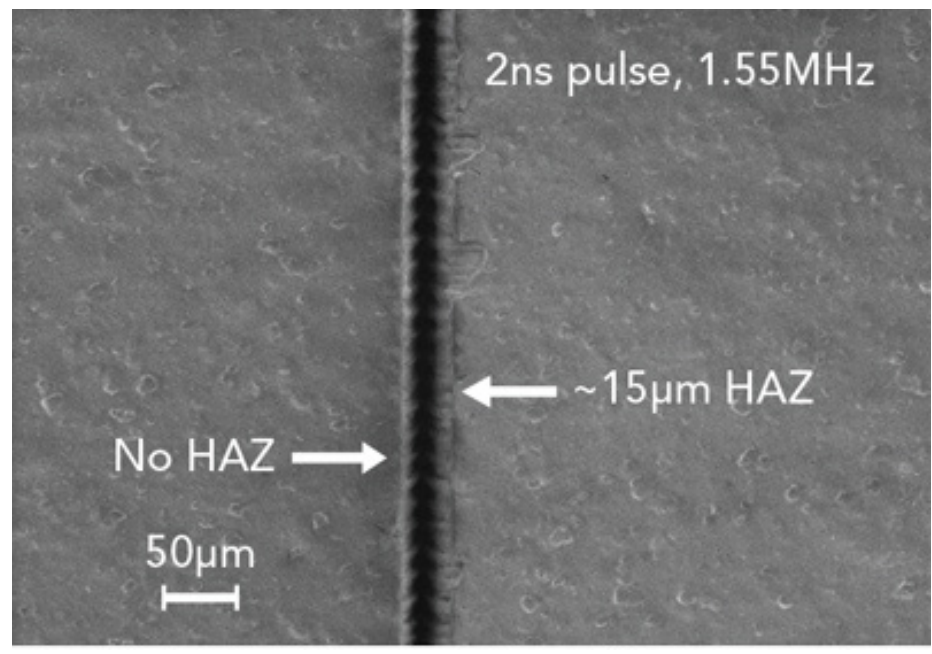

Fig. 2. CFRP edge cut with the use of an UV laser, with the HAZ marked - image from an electron microscope [2].

The laser cutting technology is most frequently used to cut flat surfaces. However, 3D laser cutters are available as well, and are capable of trimming not only flat composite panels, but also spatial components.

\subsection{Cutting composite materials with abrasive water jet}

The abrasive water jet technology eliminates two considerable problems experienced while using both laser and mechanical cutting methods. The first of those problems is the carbon dust created during the cutting process, with the other being the heat generated at the cutting spot. The materials is removed by water fed at a high pressure, which also acts as the cooling agent. This makes the method in question suitable for various types of materials, depending regardless of their melting and glass transition temperatures, as no temperature increases are experienced in the process. Hence, HAZ is not a factor too $[3,13,15]$, and the AWJ (Abrasive Water Jet) method is suitable for cutting almost any material that is up to approximately $200 \mathrm{~mm}$ thick.

As water is used during the process, hazardous carbon dust is not dispersed in the air. It is collected by the water during the cutting process, which protects the operator against the danger of inhaling the dust.

While selecting the proper cutting technology and choosing between AWJ and laser cutting, considerable attention should be paid to the thickness of the materials processed. While cutting thin 
materials, laser will prove to be much more efficient. As the thickness increases, however, the difference in the speed of cutting will become smaller, and the difference in the quality of the surface after cutting will be ever more evident, favoring the abrasive water jet method (Fig. 3).
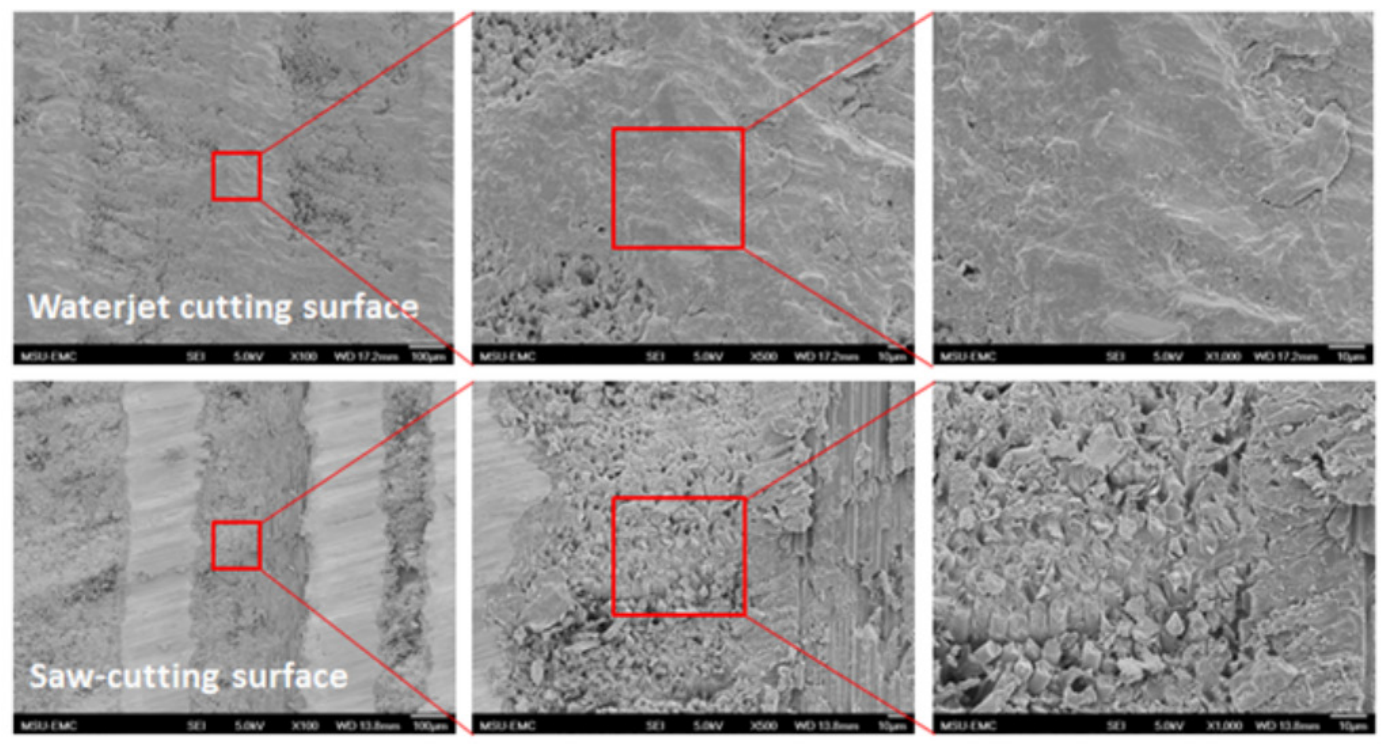

Fig. 3. Comparison of the quality of the edge cut with the use of the abrasive water jet method and a diamond disc [1]

The stage at which the material needs to be penetrated is the most difficult phase of the AWJ process. The pilot hole pierced with the use of a water jet may result in delamination adjacent to the opening. Drilling a hole that will make it possible to continue cutting with the use of the abrasive water jet seems to be the most practicable solution to the problem $[4,14,18]$.

\subsection{Machining composite materials}

The most popular methods of machining composite materials include cutting with the use of a saw and milling. Machining is the most universal method, applied not only with regard to composite materials. Saws, cutters and drills may be used to achieve very complicated shapes. However, tools used to machine CFRP are by no means cheap. Materials containing carbon fiber cause premature wear of tools made of steel, and even carbides. Tools covered with diamond particles seem to be the best solution here. They are much more expensive, but with their considerably higher longevity taken into consideration, they turn out to generate - in most cases, at least - significant savings. Periodic inspection of tools is necessary, as ones that are worn and not sharp enough may pull on the individual fibers, instead of cutting them. As the tools wear, their dimensions decrease as well. Lack of proper supervision over those fluctuations may result in the dimensions of the finished pieces failing to meet the desired standards. Compared to metal components, the process of machining CFRP requires higher rpm, but lower feed rates [5-7,16,17].

While machined with the use of a saw or a cutter, the workpiece absorbs some of the heat generated in the process. In the case of CFRP, the machining needs to be controlled to ensure that the 
temperature of the workpiece does not exceed the glass transition temperature, as once reached, irreversible changes in the structure take place that affect the properties of the area in question.

Tools with built-in cooling system are an interesting proposal for all those machining CFRP (and other components as well). Cutters and drilling bits of this type have internal channels feeding the coolant that absorbs some of the heat generated in the cutting process. Such tools are expensive, however, and require some additional accessories.

The direction of cutting or milling (relative to the position of the fibers in the workpiece) is an important consideration while machining CFRP. It needs to be noted if the tool selected is doing equally well when cutting in parallel, perpendicularly or diagonally - in relation to the position of the fibers. The direction of machining and its impact on the quality of the edge has been discussed in article [8].

In addition to heat, machining produces also carbon dust. Controlling its dispersion is very important due to its carcinogenic properties. It is necessary to use workstation hoods and extraction systems, as well as anti-dust masks.

Proper attachment of the components to be cut is a problem that needs to be considered as well. No matter whether a disc or a cutter are used, lateral forces are generated during cutting that may shift an improperly attached element. Mechanical fastening seems to be the best of the solutions, but if the elements processed need to be accessed from four directions, it is rarely possible. The problem may be solved by using a vacuum table, or double-sided adhesive tapes.

\section{SELECTION OF THE CUTTING TECHNOLOGY}

The mechanical cutting technology has been selected for use at the Composite Testing Laboratory. The milling plotter with a diamond disc adapted was definitely the cheapest of the options available. The price, however, was not the only advantage of such a solution. The dimensions of the device were an important consideration as well. A machine with the working area of $600 \times 800 \times 50 \mathrm{~mm}$ (width $\times$ length $\times$ height) measures $1300 \times 1600 \times 1500 \mathrm{~mm}$ (Fig. 4).

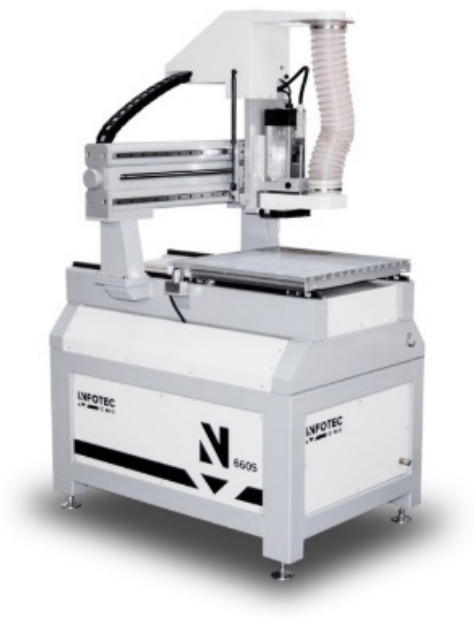

Fig. 4. INFOTEC milling plotter [10] 
The device is equipped with a 5-slot, automatic tool store, which makes the solution highly versatile. One of the slots is reserved for the adapter with the cutting discs, while the remaining ones may be used to attach tools with the use of ER32-type clamping bushings.

The mechanical cutting technology requires that the tool penetrates the entire depth of the material processed. This means that a substrate needs be used on which the material is positioned, which may also be penetrated by the cuter, drilling bit or cutting disc, once it has traveled through the entire thickness of the material cut. The aluminum working table is connected to a vacuum pump producing suction that firmly attaches the elements processed.

The space housing the spindle that rotates the tool with the maximum speed of up to $24,000 \mathrm{rpm}$ has been connected to a system of external filters extracting carbon dust generated while cutting, and thus preventing it from being dispersed throughout the room.

\section{IMPLEMENTATION OF CUTTING TECHNOLOGIES}

The principal requirement of the Composite Testing Laboratory was to enable automatic cutting with the use of a $150 \mathrm{~mm}$ diamond disc. Preliminary tests were performed on a square sample measuring $100 \times 100 \mathrm{~mm}$. The rotating speed of the diamond disc equaled $2000 \mathrm{rpm}$, and the feed rate amounted to $5 \mathrm{~mm} / \mathrm{s}$. The panel was attached to a $12 \mathrm{~mm}$ thick MDF board with double-sided adhesive tape. The board, in turn, was firmly sucked to the table by the vacuum pump. The composite panel was pressed to the MDF board by the vacuum generated. The above was possible thanks to a network of channels machined in the MDF board. Each edge has been cut to a different depth, as shown in figure 5.

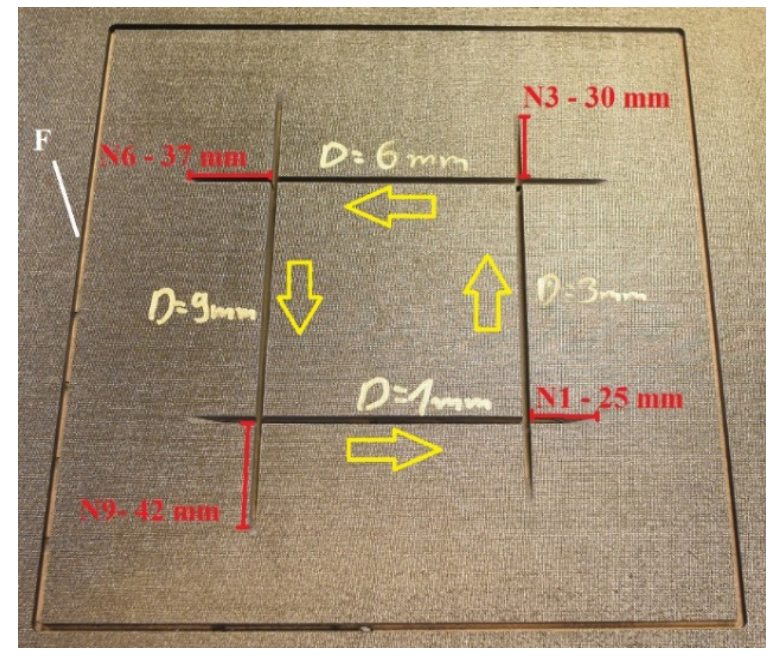

a)

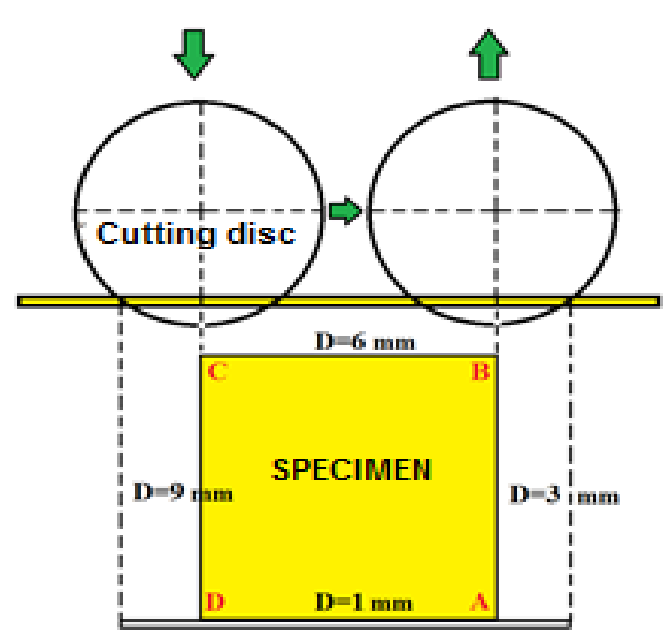

b)

Fig. 5. Cutting the test sample: a - test sample cut with the use of a diamond disc, $\mathrm{b}$ - the principle of making side incisions [own materials]

Figure 5 shows the edges with the cutting depth marked $-1 \mathrm{~mm}, 3 \mathrm{~mm}, 6 \mathrm{~mm}$ and $9 \mathrm{~mm}$, and presents the additional incisions N1, N3, N6 and N9 that cannot be avoided while cutting with the use of a disc. The control software guides the middle of the disc and does not supervise its outer part cutting 
a section of the board located further away. The manner in which side incisions are created is presented in Figure $5 \mathrm{~b}$. Yellow arrows used in the same drawing mark the direction of four disc passes. Importantly, the length of side incisions depends on the cutting depth. The depth was measured as the protrusion of the disc into the substrate material. Cutting depths achieved while using a $150 \mathrm{~mm}$ are presented in Table 1.

Table 1. Specification of cutting depths achieved while cutting with the use of a disc, and the resulting incisions [own materials]

\begin{tabular}{|c|c|}
\hline Cutting depth, $D, \mathrm{~mm}$ & Incision length, $N, \mathrm{~mm}$ \\
\hline \multicolumn{2}{|c|}{1} \\
\hline \multicolumn{2}{|c|}{25} \\
\hline 3 & 30 \\
\hline 6 & 37 \\
\hline 9 & 42 \\
\hline
\end{tabular}

The additional incisions mean that more surplus material needs to be provided at the edge of the panel. The distances between the samples cut need to be greater as well. If the sample is attached mechanically, more space is required to turn the disc around. Milling does not cause such a problem, and the material surplus required is equal to the diameter of the cutter used.

Each edge has been inspected under a microscope. The images were taken at the corner, to make sure that in addition to the side edge, the quality of the adjacent surface can be observed as well. The aim was to verify whether the penetration depth of the disc impacts the angle at which the edge is cut. The corners have been marked as shown in Figure 5 b. Images of the edge (entry and exit side) are shown in Figure 6.

Entry side edges, at the depth pf $1 \mathrm{~mm}, 3 \mathrm{~mm}, 6 \mathrm{~mm}$ and $9 \mathrm{~mm}$
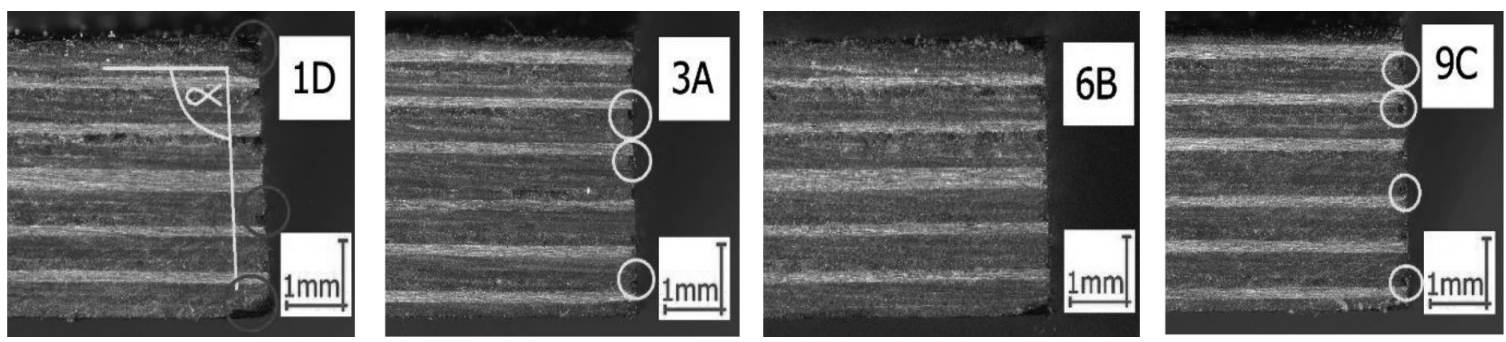

Exit side edges, at the depth pf $1 \mathrm{~mm}, 3 \mathrm{~mm}, 6 \mathrm{~mm}$ and $9 \mathrm{~mm}$
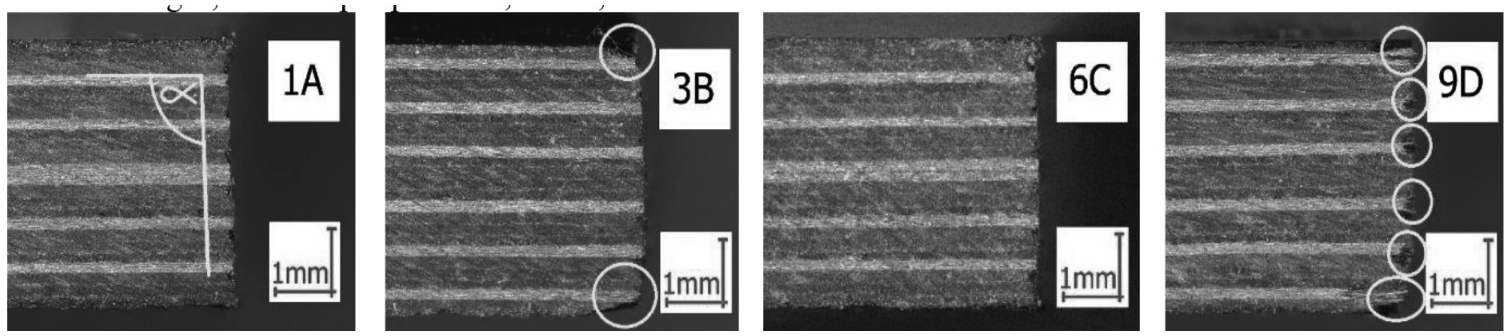

Fig. 6. Images of entry- and exit side edges cut with the use of a diamond disc, at the depth of $1 \mathrm{~mm}$,

$3 \mathrm{~mm}, 6 \mathrm{~mm}$ and $9 \mathrm{~mm}$ [own materials] 
The angle $\alpha$ of the edge cut with the use of a disc penetrating to the depth of $1 \mathrm{~mm}$ under the panel cut. The angle $\alpha$ should be a square angle. The measured value of angle $\alpha$ equaled $92^{\circ}$. Furthermore, the corner where the disc entered shows numerous torn and frayed fibers, as marked with red circles. The corner is shared with the edge cut to the depth of $9 \mathrm{~mm}$, which could have caused tearing and fraying of fibers. He same angle has been measured at the exit edge of the disc, with the penetration depth equaling $1 \mathrm{~mm}$ (Fig. 6 - 1A). No such significant edge defects have been observed here, however.

The edges of the incision cut with the use of a disc penetrating to the depth of $3 \mathrm{~mm}$ are not inclined at angle. Figure 6 shows insignificant fraying of exit edge 3A, marked with yellow circles. Sample corners which are clearly beveled, are shown at the exit edge 3B. The edges cut to the depth of $6 \mathrm{~mm}$ look the best: the entry edge 6B and the exit edge 6C, as shown in Figure 6 . The edges are perpendicular and free of any significant defects.

The edge cut with the use of a disc penetrating $9 \mathrm{~mm}$ into the substrate material shows numerous defects (Fig. 6). The frayed exit edge 9C and entry edge 9D are marked with yellow circles. The ends of fibers along the exit edge are torn out, and the corner itself is clearly beveled.

The differences in the appearance of the edges stem primarily from the time over which the edge was in contact with the diamond particles on the disc. The abrasive particles are spread approx. $7 \mathrm{~mm}$ from the outer edge of the disc only. This means that the edge of the material is in contact with the diamond particles on the disc for longer, when the cutting depths are lower.

\section{CONCLUSIONS}

Analysis of literature and the tests performed have led to formulating the following conclusions:

1. Introduction of a cutting device with an adapter for attaching a cutting disc has facilitated preparation of composite panel samples, eliminating the need of rotating the workpiece on the table. The workpiece remains in the same position throughout the process. This has reduced the lead time required to cut a lot of CFRP samples by $50 \%$.

2. MDF boards have turned out to be a very good substrate for machines with a vacuum table. The network of channels inside the board makes it possible to attach the workpiece by suction.

3. When diamond discs are used, the cutting depth needs to be selected accordingly to the height of the area on which the diamond particles are spread on the disc. The longer period of contact with the diamond particles means that the edge becomes smoother. Hence, the height of the area covered with diamond particles should be larger than the thickness of the material cut, to ensure that the particles are in contact with the edge cut throughout the entire duration of the operation.

4. Cutting with the use of a disc requires some surplus material, to accommodate the incisions created during the process. The dimensions of those incisions depend on the depth of cutting. During the tests (with a $150 \mathrm{~mm}$ disc), cuts were made to the depth of $1 \mathrm{~mm}, 3 \mathrm{~mm}, 6 \mathrm{~mm}$ and $9 \mathrm{~mm}$. These have resulted in surplus material lengths of $25 \mathrm{~mm}, 30 \mathrm{~mm}, 37 \mathrm{~mm}$ and $42 \mathrm{~mm}$, respectively.

5. The review of the machining methods available has indicated that abrasive water jet cutting offers certain advantages while processing flat CFRP sheets. However, the technology requires considerable capital expenditure, as the prices of equipment start at approximately PLN 300,000. 


\section{BIBLIOGRAPHY}

[1] Hashish M., 2013, Trimming of CFRP components, WJTA-IMCA Conference and Expo, September 9-11, 2013, Houston, Texas.

[2] Patel R., Bovatsek J., Fujita M., 2017, High-power UV laser has use in CFRP machining, http://www. industrial-lasers.com/

[3] Ohlsson L., 1995, The theory and practice of abrasive water jet cutting, Doctoral thesis 1995:161D, Lulea University of Technology.

[4] Kimlia advertising materials, www.kimla.pl, 2017.

[5] Rimpault X., Chateleain J.-F., Klemberg-Sapieha J.E., Balazinski M., 2016, Tool wear and surface quality assessment of CFRP trimming using fractal analyses of the cutting force signals, CIRP Journal of Manufacturing and Technology.

[6] Arisawa H., Akama S., Niitani H., 2012, High-performance cutting and grinding for CFRP, Mitsubishi heavy industries Technical review, Vol. 49, No. 3, pp. 3-9.

[7] Sloan J., 2017, Machining carbon composites - risky business, http://www.compositesworld.com/

[8] Castells R., 2017, Five tips for machining carbon fiber, http://www.element.com/

[9] Guangjun L., Hongyuan C., Zhen H., Fei G., Tao C., 2017, Surface quality of staggered PCD end mill in milling of carbon fiber reinforced plastics, Applied Sciences, Vol. 7.

[10] Infotec sp. z o.o. advertising materials, 2017.

[11] Szymański R., 2017, Quality control process of manufactured composite structures, Transactions of the Institute of Aviation, No. 1(246).

[12] Kozaczuk K., Zalewska M., 2016, Composite testing laboratory performance development based on Lean Sigma approach - case study, Transactions of the Institute of Aviation, No. 4(245).

[13] Jaśkiewicz R., 2016, Influence of the drilling process parameters on the quality and mechanical properties of drilling holes in carbon composites, Transactions of the Institute of Aviation, No. 3(244).

[14] Jaśkiewicz R., Stepniowska A., 2016, Methodology of outliers determination for composite materials strength tests, Transactions of the Institute of Aviation, No. 3(244).

[15] Karny M., 2016, The influence of hygrothermal conditioning on bearing strength of carbon-fiberlepoxy laminate, Transactions of the Institute of Aviation, No. 3(244).

[16] Wilk J., 2016, Development and implementation of a testing method for the characterization of interlaminar delamination propagation in laminates under fatigue mode I loading conditions, Transactions of the Institute of Aviation, No. 2(243).

[17] Jaśkiewicz R., Stepniowska A., 2016, Pracitcal application of FAA methodology of composite specimens used to material tests qualifications, Transactions of the Institute of Aviation, No. 3(244).

[18] Sałacińska A., 2016, Review of physical tests for composite materials characterization, Transactions of the Institute of Aviation, No. 3(244).

[19] Karny M. Falczyński P., 2017, The influence of the fastener hole preparation method on the fastener pull-through process in a carbon composite, Transactions of the Institute of Aviation, No. 1(246). 


\section{WDROŻENIE TECHNOLOGII ZAUTOMATYZOWANEGO CIĘCIA PRÓBEK I ELEMENTÓW KOMPOZYTOWYCH}

\section{Streszczenie}

W artykule przedstawiono metodykę wprowadzenia do użytku technologii automatycznego cięcia paneli z włókna węglowego w Laboratorium Badań Kompozytów Instytutu Lotnictwa. Artykuł zawiera opis procesu wdrożenia nowej technologii cięcia, pozwalającej na zwiększenie wydajności procesu przygotowywania próbek kompozytowych do testów wytrzymałościowych, przy zachowaniu wymogów gładkości brzegów i tolerancji wymiarowych. Artykuł zawiera również przegląd literatury na temat trzech najpopularniejszych metod cięcia materiałów kompozytowych: cięcia laserowego, cięcia wodą i cięcia mechanicznego, wskazując zalety i wady każdej z metod. Po wybraniu technologii obróbki mechanicznej z użyciem tarczy, przeprowadzono testy cięcia. Przedmiotem testów były tarcze tnące z nasypem diamentowym, a przedmiotem obrabianym panele z włókna węglowego. Obróbkę testową wykonano na maszynie sterowanej numerycznie firmy INFOTEC CNC, z adapterem do tarcz tnących o maksymalnej średnicy $150 \mathrm{~mm}$.

Słowa kluczowe: cięcie kompozytów, cięcie automatyczne, cięcie CNC, obróbka mechaniczna włókien węglowych. 